\title{
Scrum agile product development method - literature review, analysis and classification
}

\author{
Bernardo Vasconcelos de Carvalho, ${ }^{a}$ Carlos Henrique Pereira Mellob \\ University Center of Itajubá \\ bFederal University at Itajubá \\ e-mails: bernardovc@yahoo.com.br; carlos.mello@unifei.edu.br
}

\begin{abstract}
The aim of this paper was to present a review, an analysis, and a classification and coding of the literature on the Scrum method. Publications of interest were found through a search on CAPES periodicals database. Those publications were classified according to their origin, year of publication, type of study, approach, authors' membership, and reporting period. An investigation was conducted in order to find the benefits of using the Scrum method. Results showed that the literature on the subject is still scarce, but it is expanding and presents a lack of longitudinal and quantitative studies. It was concluded that there is a great demand for the generation of scientific knowledge on the subject.
\end{abstract}

Keywords: scrum method, agile product development, literature review, literature classification.

\section{Introduction}

In today's software development environment requirements have been subject to constant changes during the product development cycle so that they can respond to shifts in demand (RISING; JANOFF, 2000). Therefore, software development becomes a challenge, mainly to small businesses due to their scarce resources.

In the mid 90's, agile development tecniques for software products became available. This discipline was strongly influenced by the Japanese industry best practices, mainly the lean manufacturing principles implemented by Honda and Toyota as well as the Knowledge Management strategies suggested by Takeuchi and Nonaka (2004) and Senge (1990).

In this context, Scrum, a lean product development approach is highlighted. This process was developed by Jeff Sutherland in 1993. It was based on a Takeuchi and Nonaka (1986) article which discusses the advantages of small teams in product development.

Agile software development methods have gained popularity lately. However, there are a few empirical studies about it. A recent systematic literature review (DYBÅ; DINGS $\varnothing Y R, 2008$ ) identified 1996 articles on agile methods in general from which 36 , or $1.8 \%$, were empirical studies that could be acceptable in regards to methodology, credibility and relevance.

Besides Scrum, other agile methods are worth mentioning, such as: Agile Modeling, AUP (Agile Unified Process), Agile Data Method, DSDM (Dynamic Systems Development Method), EssUP (Essential Unified Process),
XP (Extreme programming), FDD (Feature Driven Development), Getting Real e OpenUP (Open Unified Process). All of them have their own application niche and specificities, but they are all interactive and incremental, i.e., they follow agile principles (LARMAN; BASILI, 2003). Some of them may be used simultaneously, as seen in the partnership between XP and Scrum (VRIENS, 2003). This work paper will focus on Scrum for its popularity, its capacity to adapt to small teams and its client orientation.

This way, the aim of this paper is to present a review of the literature on the subject together with an analysis, a classification and a codification of the articles found. Then, it will be possible to check the characteristics of the studies carried out and identify possible trends and academic needs on the subject.

\section{Scrum principles}

Product development is a complex activity, especially for smaller companies which have great resource limitations. According to Mundim et al. (2002), product development has something to do with basically all other roles in a company. The reason for that is that in order to develop a product certain kinds of information and abilities are required from all members of all functional areas, which makes it, basically, a multitask activity. Moreover, it's an ad hoc feature, in which each project of development may show specific characteristics and a unique background.

Throughout the years, several methodologies of product development have been presented. Among them, there are 
the so called agile (AMBLER, 2002) or light (FOWLER, 2000) methods. They are adaptable and flexible development methodologies and are indicated to scenarios where demand shifting is constant and results must be delivered to the client in short periods of time. The proposal of these methodologies is to split development into short cycles or iterations a few weeks long so that at the end of each cycle the in-house or outside client may get a version that adds value to the business (DANTAS, 2003). This way, developers may not only follow demand shifts at the beginning of each cycle but also have continuous client feedback and, therefore, cut down project risks.

While traditional development methodologies focus on project document generation and on the strict fulfillment of processes, the agile proposal is to focus on development itself and on participants' relationships (MUNDIM et al., 2002). The initial planning phase is reduced for the developers to concentrate on each iteration instead of having to draw guidelines for the project as a whole.

Following this agile proposal line, the Scrum method has the objective, according to Schwaber and Beedle (2002), to define a process for the project which is focused on people. The Scrum idea comes from a comparison between developers and Rugby players. Scrum is the name of the quick meeting players have when they are about the start a move. The first time the expression was used was in a study by Takeuchi and Nonaka (1986). In that study the researchers noted that small projects led by small multitask teams had the best results.

In Rugby each team acts as a whole, as an integrated unit in which each member develops a specific role and everyone helps reach a common objective. That is also true for teams who adopt the Scrum process.

Scrum was created by Jeff Sutherland, Ken Schwaber and Mike Beedle, and is based on six characteristics (SCHWABER, 1995):

- Result flexibility;

- Deadline flexibility;

- Small teams;

- Frequent reviews;

- Cooperation;

- Object orientation.

This method doesn't require or provide any specific technique for the development phase. It only establishes a group of rules and management practices that must adopted for the success of the project.

The Scrum management practices are:

- Product backlog;

- Daily scrum;

- Sprint;

- Sprint planning meeting;

- Sprint backlog;

- Sprint review meeting.
Scrum's initial point is Product Backlog. This practice is considered the one responsible for demand gathering, according to Schwaber and Beedle (2002). In this initial point, through meetings with all staff involved along with investors and project partners the items, the business needs and all the technical demands to be developed are pointed out. Thus, Product Backlog is a list of activities which will be developed during the project.

The Daily Scrum is a quick daily meeting that gathers all team members to define which will be the daily tasks and to know the results of the previous day's tasks. This meeting is also called Stand Up Meeting, since it is common to have everyone standing up during the meeting. Three questions must be answered by every member about their responsibilities (RISING; JANOFF, 2000):

- What was done yesterday?

- What will be done today?

- Is there any obstacle to the accomplishment of your tasks?

Sprint is considered the main Scrum practice. Here all work tasks defined in the Product Backlog are implemented by the Scrum team. This may last from one to four weeks. According to Abrahamsson (2002), in the case of software development, Sprint included the traditional phases of software development: demand, analyses, project and delivery.

Sprint Planning Meeting is the meeting in which the team plans its Sprint. Sprint Backlog is a subgroup of Product Backlog. In other words, it is a list of activities that must be carried out during the Sprint. On the other hand, the Sprint Review Meeting is the meeting that happens after each Sprint. In this meeting, the team discusses what went wrong or right and lessons learned.

Figure 1 shows a general idea of the dynamics of how the Scrum process works (MAR; SCHWABER, 2001). In the beginning, client and developers define the Backlog, or a list of demands for the product. The due dates are also defined taking the clients requests into account; then, the costs of the project are estimated; an initial risks analysis is prepared; the work tools and the team members are chosen. One of the developers is designated Scrum Master, whose job is similar to that of the project manager (though there are major differences between a Scrum Master and a Project Manager).

The person who is designated as the Scrum Master must make sure the Scrum process happens and that there are no barriers for the team members to do their jobs. Removing barriers appointed by the Daily Scrum is his duty, so that the developers may concentrate only on technical issues.

Another important role in the method is that of the Product Owner. This member of the team represents the internal or the external client. He must define the demands and rank each one by importance and priority. 


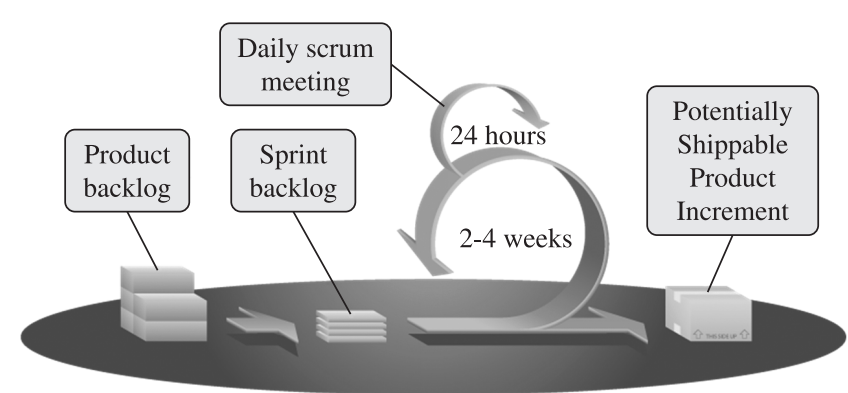

Figure 1. General idea of the scrum process dynamics. Source: Cohn (2008).

Traditionally, the development cycles (Sprints) last around thirty days (SCHWABER, 1995). According to Figure 1, in the beginning of each Sprint, the teams make a list of the tasks that must be accomplished in that Sprint (Sprint Backlog) and the tasks are handed out. The developers discuss the patterns which will be adopted and the tasks of analysis, coding and testing are initiated. At the end of each Sprint, a new version of the product (in the case of a software product, an executable) is presented to the client for feedback. The identified flaws are added to the Project Backlog. Throughout the project, Scrum management mechanisms such as control follow-up are applied. The number of functions not delivered, the need of changes to correct deficiencies or for technological updates, the technical problems found and the risks and the strategies to avoid them are examples of control actions observed during the development.

\section{Research method}

The research method used for this paper was a thorough review of the literature on the Scrum method. The purpose of the review was to identify among worldwide published research papers everything that has been published with Scrum as its main or secondary subject. Therefore, this paper work method may be characterized as quantitativetheoretical and conceptual.

It is important to highlight that in order to identify, locate and access publications of interest all database available at CAPES (Coordenação de Aperfeiçoamento de Pessoal de Nível Superior) which could result in a relevant article in the Scrum field were accessed. They are AAAS, ACM, ACS, AIP, Annual Reviews, Begen House, Bentham Science, BioOne, Balackwell, Cambridge University Pres, Cold Sprint Harbor Laboratory, Duke University Press, EBSCO, Emerald, Gale, Guilford Press, HighWire Press, IEEE, Informs, IOP, JSTOR, Karger, Maney Publishing, Nature, OECD, OVID, Oxford University Press, Red CLACSO, ProQuest, Sage, SciELO, Science Direct, Slack Inc., Springer, Thieme, Wilson e World Scientific. According to Carnevalli and Miguel (2007), a work of such nature (literature review) must take into account all database available at CAPES due to its wide scope and ease of access to most researchers in Brazil.

The research was carried out between the $15^{\text {th }}$ and the $17^{\text {th }}$ of October 2008. The key word used for the research was "Scrum". At first, the search was by work title. Next, the search was filtered by the abstract field. The publication date was not used as filter. That way, articles published at any time were included.

Initially, 48 papers were identified. However, eight of them were discarded - seven of them were about Rugby and related to sports and the eighth was from the medical field and dealt with a substance named "Scrum OestradioI-17-b". Consequently, the universe of investigation for this research paper was of forty articles.

For the data analyses the authors opted to taken into consideration articles published in journals, congresses and international symposiums. Dissertations and theses were not included since the CAPES periodicals database presents a limited number of those, which would not correspond to the large number of such papers annually being completed in the country. Worldwide, it would have been even more complicated to include dissertations and theses due to the large number of universities that would have to be looked into. Therefore, that is a limitation of this work, i.e., only work published in indexed journals, congresses and international symposiums have been investigated.

An adaptation of the Carnevalli and Miguel (2007) method was used for the sorting of the articles, which were, then, catalogued and sorted out into two main groups entitled Conceptual Research and Empirical Research.

The works classified as Conceptual Research were later sub-classified under Theoretical/Conceptual, Literature Review, Simulation and Theoretical Modeling. On the other hand, those classified under Empirical Research were sub-divided into Survey, Case Study, Action Research and Experimental Research.

The other classification criteria adopted was the year of publication, the origin of the data and the time period of analyses and were denominated as Current, Longitudinal and Retrospective. The author affiliation was classified as University, Research Center and Company.

Another goal was to find out which benefits of Scrum are mentioned in the literature. A group of nine benefits was identified and these benefits were mapped along those articles. In the following section of this paper we present the main findings of this research study.

\section{Results}

Although the Scrum method is popular on the Internet and at companies, it is not a simple task to find scholar material on the subject. However, this study shows that this 
scenario is about to change. The increase in publications on Scrum has been remarkable along the years (Figure 2). For instance, if this study had been carried out in 2006 only 11 articles would have been found in our database.

This growth may also be seen in Figure 3, which shows that $73 \%$ of the literature on Scrum was published in the last two years (2007 and 2008). Besides that, taking into account that the research was carried out in October 2008, we believe these numbers have grown even more since then. A hypothesis for this increase along the years is the gradual implementation of the method by companies, which, consequently, is leading scholars toward the subject.

The oldest publication, despite its current approach, is the one of Rising and Janoff (2000). This is a historic

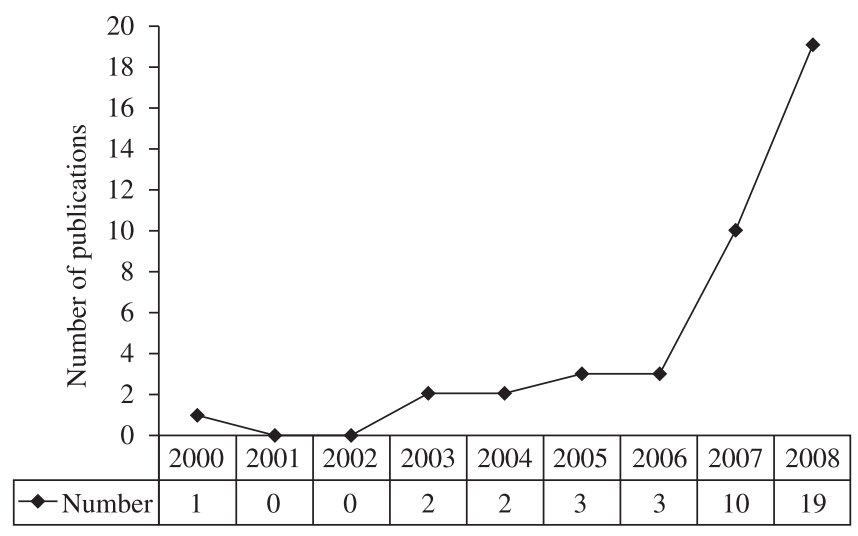

Figure 2. Number of publications by year of publication.

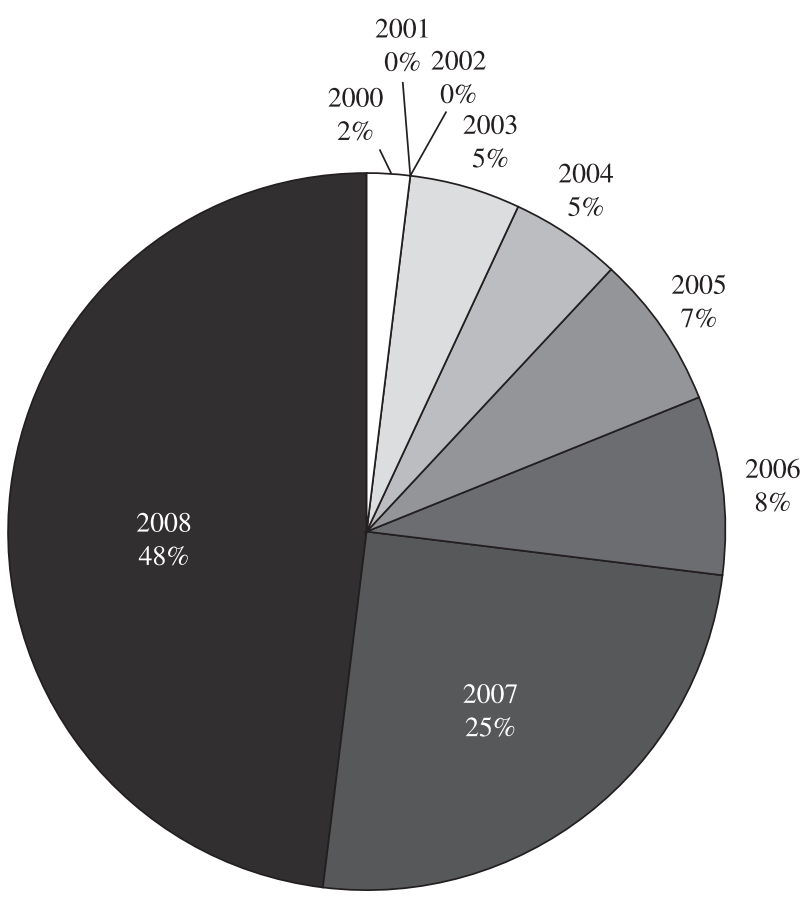

Figure 3. Publications distribution by year of publication. publishing which introduced Scrum to scholars. Only three years after that new articles about Scrum were published.

Another aspect to be pointed out is the large concentration of publications about Scrum available at the IEEE and ACM database. Those two databases together account for $94 \%$ of the publications found. Figure 4 shows that as well as the participation of AIP and Science Direct.

Figure 5 shows the result of the classification by type of study. As we can see the most common types are Case Study and Theoretical/Conceptual methods. Perhaps the low number of those classified as Literature Review is due to the lack of material on the subject. The few research studies which were classified as Survey and Action Research may disclose how immature the subject is.

Next, as it can be seen in Figure 6, the method of work investigation shows that most studies were qualitative. There were only three quantitative articles which included Salo and Abrahamsson (2008) e Sulaiman et al. (2006).

As expected, due to how young the subject is, no article was found which could be classified as retrospective analyses. As we can see in Figure 7 almost all the articles are current, with the exception of the work done by Mann and Maurer (2005), which performs a longitudinal analyses (a two-year case study) to measure the impact of Scrum on client satisfaction.

Figure 8 brings information that deserves our attention. It shows the authors affiliation. Differently from what we see with other subjects, most Scrum researchers are in companies, mainly software related and not in universities

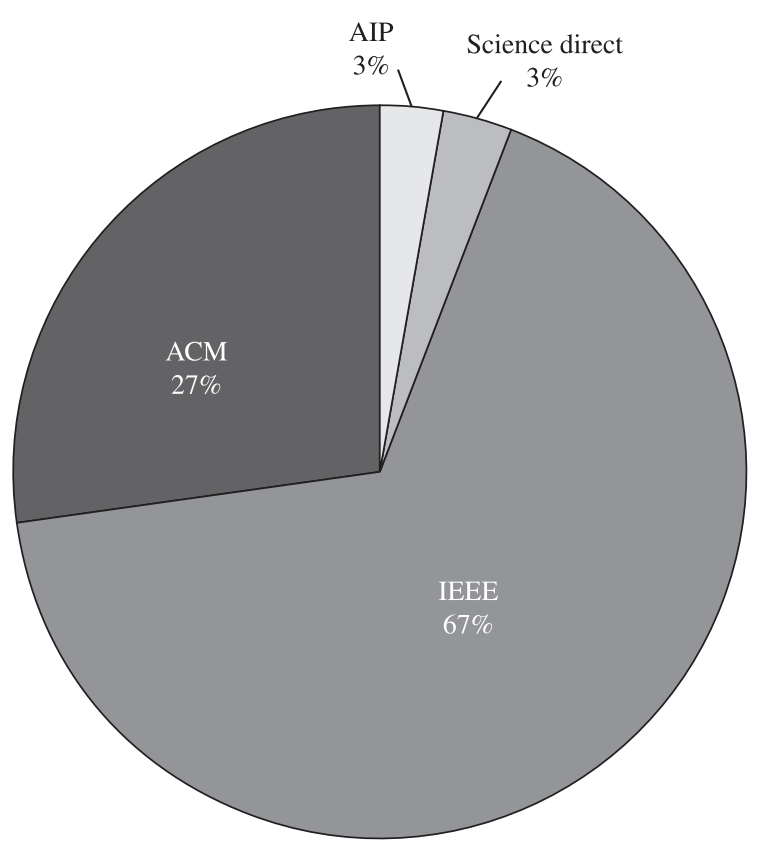

Figure 4. Publication distribution by database. 


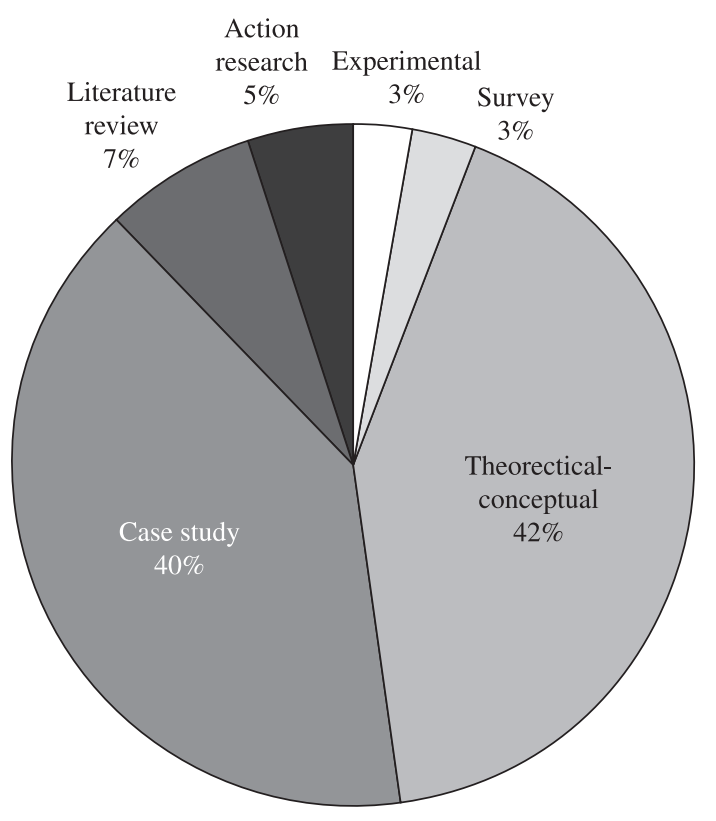

Figure 5. Publication distribution by method of study.

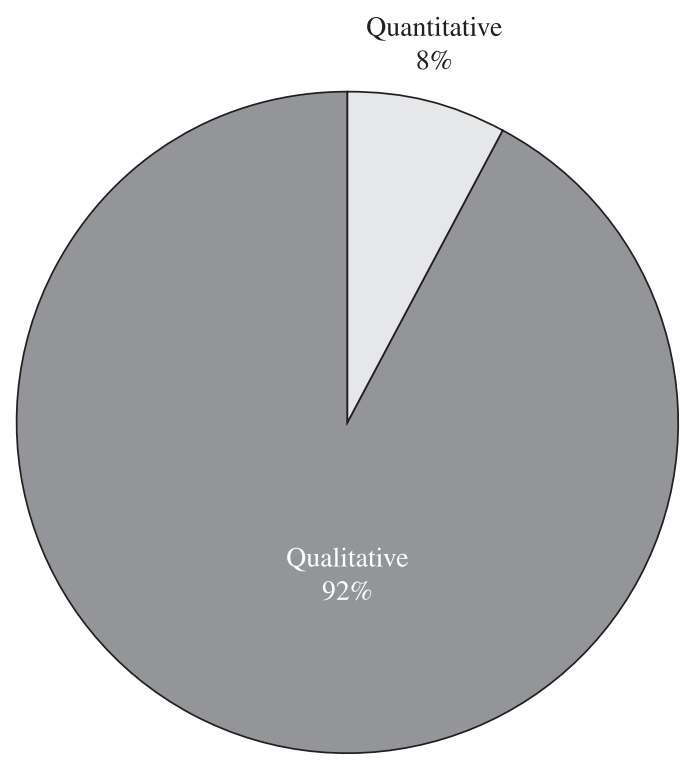

Figure 6. Publication distribution by approach.

and research centers. That may be explained by the fact that Scrum had its origins in the software industry and was implemented by specialists in the field. Only more recently Scrum called the attention of academic researchers who have started to study it more scientifically.

Finally, the most mentioned benefits of using Scrum were mapped. Those benefits may be seen on Table 1 and Figure 9. An analysis of those benefits shows that the most mentioned one is the improvement in communication and the increase in collaboration among those involved. This was not a surprise since Scrum is oriented towards people

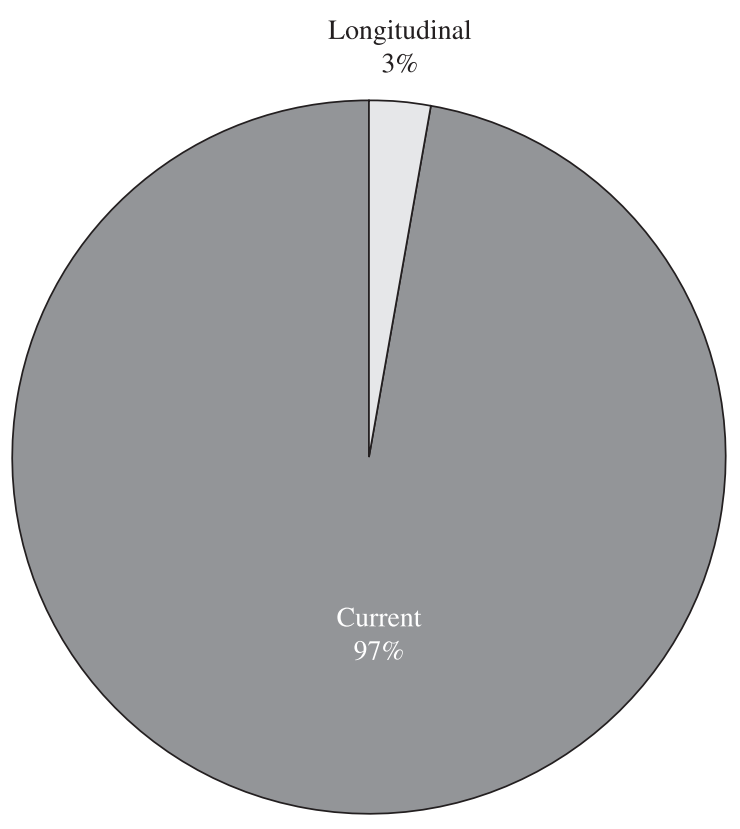

Figure 7. Publication distribution by analyses period.

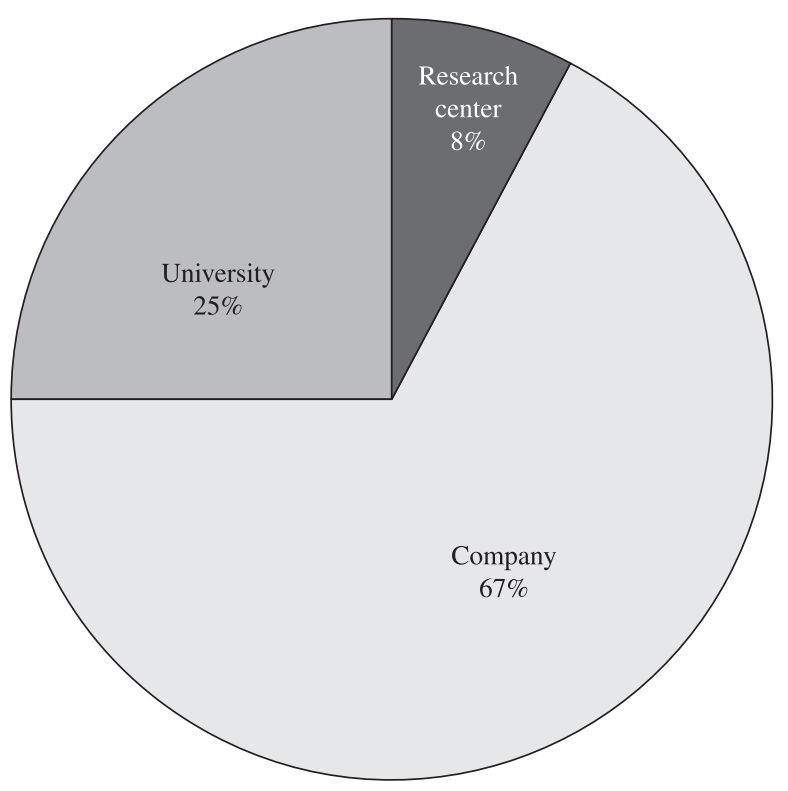

Figure 8. Publication distribution by authors' affiliation.

and one of its basic elements is in fact the high cooperation among team members. What surprised us was the second most mentioned benefit: improvement in the quality of the product. Initially, Scrum was not proposed with focus on quality. However, its features ended up having a meaningful impact on quality improvement.

Another point of study was the percentage of articles presented in congresses in comparison to articles found in journals, according to the previously mentioned database. The result of this classification can be observed in Figure 10. The concentration of articles in congresses is clear. 
Table 1. Scrum benefits and its corresponding codes.

\begin{tabular}{|c|l|c|}
\hline Code & \multicolumn{1}{|c|}{ Benefit } & Number of times cited \\
\hline A & Increase in client satisfaction (decrease in number of complaints) & 9 \\
\hline B & Improvement in communication and increase in cooperation among team members & 13 \\
\hline C & Increase in project return on investment & 6 \\
\hline D & Increase in development team motivation & 5 \\
\hline E & Improvement in product quality & 11 \\
\hline F & Decrease in manufacturing costs & 3 \\
\hline G & Increase in team productivity & 10 \\
\hline H & Decrease in time to conclude projects & 3 \\
\hline I & Decrease in project risk (lower failure possibility) & 1 \\
\hline
\end{tabular}

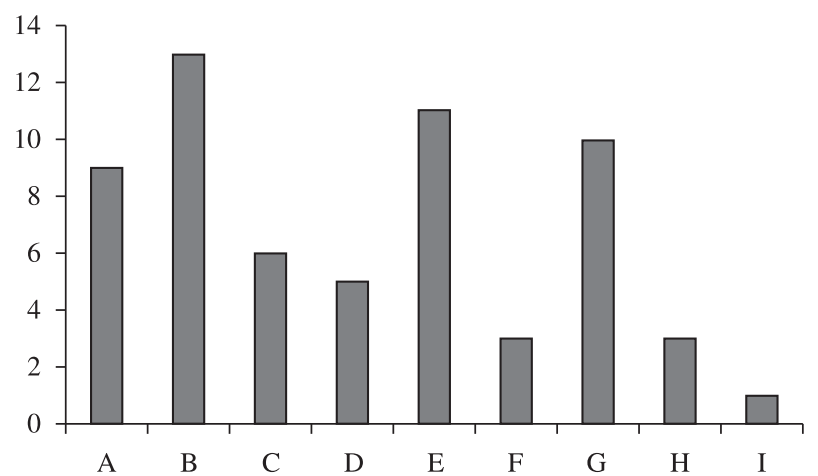

Figure 9. Number of benefits mentioned.

This concentration on congresses called the researchers attention and lead them to check whether a specific event would have more articles presented than others. As it can be seen on Figure 11, three congresses are in evidence. The one with the higher number of articles is The Agile Conference, which has published eleven articles on Scrum, and which represents $59 \%$ of all the articles in such events. The other notable events are ICSE (International Conference on Software Engineering) and Hawaii International Conference on System Sciences, which have published three and two articles, respectively.

Another point worth mentioning is the fact that the journals where most of the articles were published are relevant and of high quality. For instance, IET Software, System Sciences and The Journal of Product Innovation Management are some of them and their impact factors are respectively $1.157,1.185$ e 1.585 .

All these results are presented in more detail in Appendix A, where there is a classification of each of the 40 articles. In the same Appendix there is also the corresponding journal for each article together with its database, year of publication (Table 2), type of study, approach method, researcher affiliation, period of analysis and the Scrum benefits (Table 3).

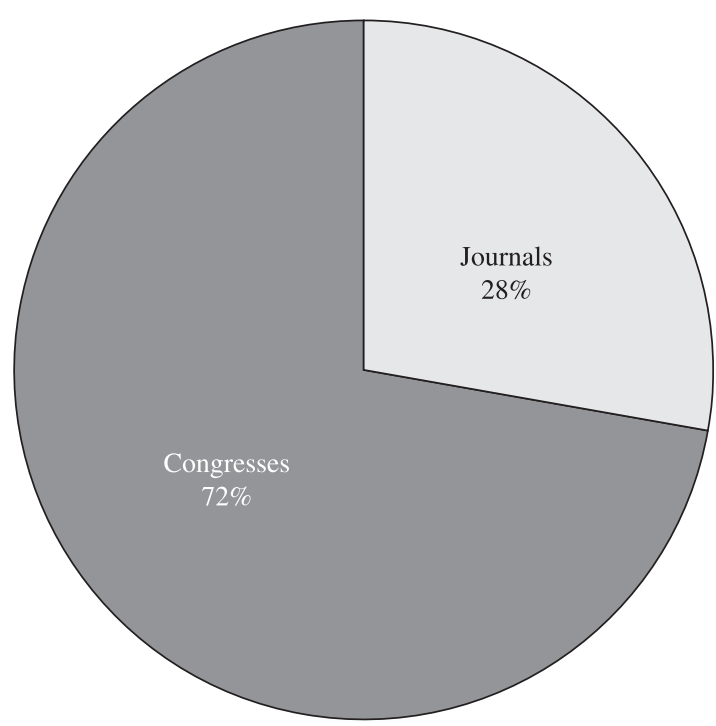

Figure 10. Number of benefits citation.

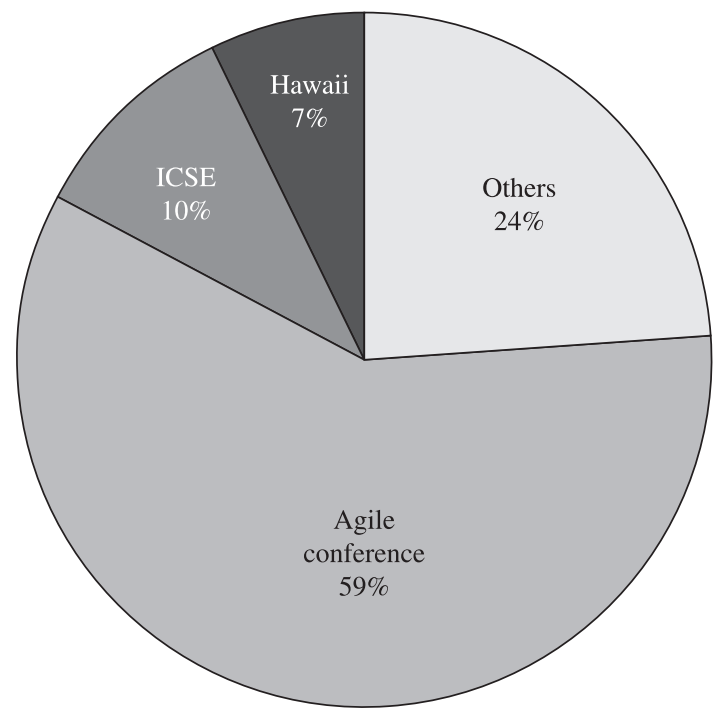

Figure 11. Events with most articles on Scrum presented. 


\section{Conclusions and suggestions for future study}

According to the data collected, it is possible to conclude that the literature on Scrum is scarce, but growing. If the tendencies are confirmed, in a few years there will be more publications on this topic. It is also possible to observe that there is great concentration of publication in a few journals and databases. The growth in the number of publications in the last couple of years may raise interest on publication about this topic in other databases.

It is also clear that the literature lacks longitudinal and quantitative studies on this subject. Therefore, other works covering those aspects have large chances of being accepted by the scientific community.

The fact that quality improvement was such a mentioned benefit takes us to raise the hypothesis that Scrum has strong impact on product quality. However, more accurate studies are necessary to test that hypothesis, which would demand hard research work.

This study also concludes that Scrum is still mainly a managerial tool with a weak scholar perspective. That suggests that there is a scientific gap to be filled by researchers. On that account, research papers that show thorough action research focused on the implementation of Scrum in high-tech small businesses, whether they are software based or not, may be appealing future study proposals.

Finally, it is possible to say that the present study met its objectives, since it presented the state of the art on the application of Scrum in scholar research studies. This study has also shown possible areas or opportunities to foster the number of studies about the subject.

\section{References}

AMBLER, S. Agile Modeling: Effective Practices for eXtreme Programming and the Unified Process. New York: Wiley Computer Publishing, 2002. 402 p.

ABRAHAMSSON, P.; SALO, O. Agile Software Development Methods - Review and Analysis. VTT Publications, 2002. $112 \mathrm{p}$.

BARTON, B.; CAMPBELL, E. Implementing a Professional Services Organization Using Type C Scrum. In: HAWAII INTERNATIONAL CONFERENCE ON SYSTEM SCIENCES, 40., 2007, Waikoloa. Proceedings... IEEE Computer Society Press, 2007. 275 p.

BATES, C.; YATES, S. Scrum down a software engineer and a sociologist explore the implementation of an agile method. INTERNATIONAL WORKSHOP ON COOPERATIVE AND HUMAN ASPECTS OF SOFTWARE ENGINEERING - CHASE, 2008, Leipzig. Proceedings... ACM, 2008. p. 13-16.
BERCZUK, S. Back to basics: the Role of Agile Principles in Success with an Distributed Scrum Team. In: AGILE CONFERENCE, 2007, Washington. Proceedings... Washington: Agile Alliance, 2007. p. 382-388.

BERCZUK, S. et al. What's so eXtreme about doing things right. In: INTERNATIONAL CONFERENCE ON OBJECT-ORIENTED PROGRAMMING, SYSTEMS, LANGUAGES AND APPLICATIONS, 2003, San Diego. Proceedings... ACM, 2003. p. 26-30.

BRUEGGE, B. SCHILLER, J. Word Spotting in Scrum Meetings. In: INTERNATIONAL CONFERENCE ON DATABASE AND EXPERT SYSTEMS APPLICATION, 19., 2008, Turin. Proceedings... IEEE Computer Society, 2008. p. 125-129.

CARNEVALLI, J.; MIGUEL, P. C. Revisão, análise e classificação da literatura sobre o QFD - tipos de pesquisa, dificuldades de uso e benefícios do método. Gestão e Produção, v. 14, n. 3, p. 557-579, 2007. http://dx.doi. org/10.1590/S0104-530X2007000300011

COHN, M. Mountain Goat Software. 2008. Available from: $<$ http://www.mountaingoatsoftware. com/scrum $>$. Access in: dez. 2008.

CRISTAL, M.; WILDT, D.; PRIKLADNICKI, R. Usage of SCRUM: Practices within a Global Company. In: IEEE INTERNATIONAL CONFERENCE ON GLOBAL SOFTWARE ENGINEERING, 2008, Bangalore. Proceedings... Global Software Engineering, 2008. 222-226.

DANTAS, V. F. Uma Metodologia para o Desenvolvimento de Aplicações Web num Cenário Global. 2003. 112 f. Dissertação (Mestrado em Informática)-Universidade Federal de Campina Grande, Campina Grande, 2003.

DOERNHOEFER, M. Surfing the net for software engineering notes. ACM SIGSOFT Software Engineering Notes, v. 29, n. 5, p. 20-29, 2004. http://dx.doi. org/10.1145/1022494.1022500

DYBÅ, T.; DINGSØYR, T. Empirical Studies of Agile Software Development: a Systematic Review. Information and Software Technology, v. 50, p. 833-839, 2008. http://dx.doi.org/10.1016/j.infsof.2008.01.006

EDWARDS, M. Overhauling a Failed Project Using Out of the Box Scrum. In: AGILE CONFERENCE, 2008, Toronto. Proceedings... Toronto: Agile Alliance, 2008. p. 413-416.

FOWLER, M. Put Your Process on a Diet, Software Development. 2000. Available from: <http://www. sdmagazine.com/articles/2000/0012/>. Access in: dez. 2008.

FRASER, S. et al. A fishbowl with piranhas coalescence, convergence or divergence. In: OOPSLA - DYNAMIC 
LANGUAGES SYMPOSIUM, 2006, Portland. Proceedings... Hasso-Plattner-Institut, 2006. p. 937-939.

JUDY, K.; KRUMINS-BEENS, I. Great Scrums Need Great Product Owners - Unbounded Collaboration and Collective Product Ownership. In: HAWAII INTERNATIONAL CONFERENCE ON SYSTEM SCIENCES,41., 2008, Waikoloa. Proceedings... IEEE Computer Society Press, 2008. p. 62-462.

KEENAN, F. Agile process tailoring and problem analysis (APTLY). In: INTERNATIONAL CONFERENCE ON SOFTWARE ENGINEERING, 26., 2004, Edinburgh. Proceedings... IEEE Computer Society, 2004. p. 271-273.

KNIBERG, H.; FARHANG, R. Bootstrapping Scrum and XP under Crisis. In: AGILE CONFERENCE, 2008, Toronto. Proceedings... Toronto: Agile Alliance, 2008. p. 436-444.

LARMAN, C.; BASILI, V. R. Interative and Incremental Development: A Brief History. Computer, v. 36, n. 6, p. 47-56, 2003.

LEWIS, J.; NEHER, K. Over the Waterfall in a Barrel - MSIT Adventures in Scrum. In: AGILE CONFERENCE, 2007, Washington. Proceedings... Washington: Agile Alliance, 2007. p. 389-394.

LUKANUSKI, M. et al. Agile or awkward surviving and flourishing in an agile scrum project. In: CONFERENCE ON HUMAN FACTORS IN COMPUTING SYSTEMS, 2008, Porto Alegre. Proceedings... ACM, 2008. p. 2253-2256.

LYON, R.; EVANS, M. Scaling up Pushing Scrum out of its Comfort Zone. In: AGILE CONFERENCE, 2008, Toronto. Proceedings... Toronto: Agile Alliance, 2008. p. 395-400.

MAHNIC, V.; ZABKAR, N. Measurement repository for Scrum-based software development process. In: INTERNATIONAL CONFERENCE ON COMPUTER ENGINEERING AND APPLICATIONS, 2008, Acapulco. Proceedings... World Scientific and Engineering Academy and Society, 2008. p. 23-28.

MANN, C.; MAURER, F. A Case Study on the Impact of Scrum on Overtime and Customer Satisfaction. In: AGILE DEVELOPMENT CONFERENCE, 2005, Salt Lake City. Proceedings... IEEE Cumputer Society, 2005. p. 70-79.

MAR, K.; SCHWABER, K. Scrum With XP. 2001. Available from: <http://www.controlchaos.com/XPKane.htm>. Access in: dez. 2008.

MARÇAL, A. et al. Mapping CMMI Project Management Process Areas to SCRUM Practices. In: IEEE SOFTWARE ENGINEERING WORKSHOP - SEW, 2007, Loyola College. Proceedings... IEEE Computer Society, 2007. p. 13-22.

MARCHENKO, A.; ABRAHAMSSON, P. Scrum in a Multiproject Environment an Ethnographically-Inspired Case Study on the Adoption Challenges. In: AGILE
CONFERENCE, 2008, Toronto. Proceedings... Toronto: Agile Alliance, 2008. p. 15-26.

MAURER, F.; MELNIK, G. Agile methods moving towards the mainstream of the software industry. In: INTERNATIONAL CONFERENCE ON SOFTWARE ENGINEERING, 28., 2006, Shanghai. Proceedings... New York: ACM, 2006. p. 1057-1058.

MAURER, F.; MELNIK, G. Agile Methods: Crossing the Chasm. In: INTERNATIONAL CONFERENCE ON SOFTWARE ENGINEERING, 29., 2007, Minneapolis. Proceedings... IEEE Computer Society, 2007. p. 176-177.

MOORE, R. et al. Scrum at a Fortune 500 Manufacturing Company. In: AGILE CONFERENCE, 2007, Washington. Proceedings... Washington: Agile Alliance, 2007. p. 175-180. 2007.

MUNDIM, A. P. F. et al. Aplicando o cenário de desenvolvimento de produtos em um caso prático de capacitação profissional. Gestão \& Produção, v. 9, n. 1, p. 1-16, 2002.

RISING, L.; JANOFF, N. S. The Scrum Software Development Process for Small Teams. IEEE Software, v. 17, v. 4, p. 26-32, 2000.

SCHWABER, K. SCRUM Development Process. 1995. Available from: <http://jeffsutherland.com/oopsla/ schwapub.pdf>. Access in: dez. 2008.

SCHWABER, K.; BEEDLE, M. Agile Software Development with SCRUM. Prentice Hall, 2002. 158 p.

PAASIVAARA, M.; DURASIEWICZ, S.; LASSENIUS, C. Distributed Agile Development: Using Scrum in a Large Project. In: IEEE INTERNATIONAL CONFERENCE ON GLOBAL SOFTWARE ENGINEERING, 2008, Bangalore. Proceedings... Global Software Engineering, 2008. p. 87-95.

RAYHAN, S.; HAQUE, N. Incremental Adoption of Scrum for Successful Delivery of an IT Project in a Remote Setup. In: AGILE CONFERENCE, 2008, Toronto. Proceedings... Toronto: Agile Alliance, 2008. p. 351-355.

RISING, L.; JANOFF, N. The Scrum software development process for small teams. IEEE Software, v. 17, n. 4, p. 26-32, 2000. http://dx.doi.org/10.1109/52.854065

SALO, O.; ABRAHAMSSON, P. Agile methods in European embedded software development organizations. IET Software, v. 2, n. 1, p. 58-64, 2008. http://dx.doi. org/10.1049/iet-sen:20070038

SANDERS, D. Using Scrum to manage student projects. Journal of Computing Sciences in Colleges, v. 23, n. 1, p. 70-80, 2007.

SCOTLAND, K.; BOUTIN, A. Integrating Scrum with the Process Framework at Yahoo!. EUROPE AGILE CONFERENCE, 2008, Girona. Proceedings... GI Science, 2008. p. 191-195. 
SENGE, P. The Fifth Discipline: the Art and Practice of the Learning Organization. New York: Currency, 1990. 409.

SMITH, P. Agile Project Management Creating Innovative Products. The Journal of Product Innovation Management, v. 20, n. 4, p. 369-376, 2005. http://dx.doi. org/10.1111/j.0737-6782.2005.133_1.x

SMITS, H.; PSHIGODA, G. Implementing Scrum in a Distributed Software Development Organization. In: AGILE CONFERENCE, 2007, Washington. Proceedings... Washington: Agile Alliance, 2007. p. 371-375.

SULAIMAN, T.; BARTON, B.; BLACKBURN, T. Agile EVM - Earned Value Management in Scrum Projects. In: AGILE CONFERENCE, 2006, Minnesota. Proceedings... Minnesota: IEEE Computer Society, 2006. p. 23-28.

SUTHERLAND, J. Future of Scrum Parallel Pipelining of Sprints in Complex Projects. In: AGILE CONFERENCE, 2005, Denver. Proceedings... Denver: Agile Alliance, 2005. p. 90-99.

SUTHERLAND, J.; JAKOBSEN, C.; JOHNSON, K. Scrum and CMMI Level 5. The Magic Potion for Code Warriors. In: AGILE CONFERENCE, 2007, Washington. Proceedings... Washington: Agile Alliance, 2007. p. 272-278.

SUTHERLAND, J.; JAKOBSEN, C.; JOHNSON, K. Scrum and CMMI Level 5. The Magic Potion for Code Warriors. In: HAWAII INTERNATIONAL CONFERENCE ON SYSTEM SCIENCES, 41., 2008, Waikoloa. Proceedings... IEEE Computer Society Press, 2008.p. 466-466.
SUTHERLAND, J. et al. Fully Distributed Scrum. The Secret Sauce for Hyperproductive Offshored Development Teams. In: AGILE CONFERENCE, 2008, Toronto. Proceedings... Toronto: Agile Alliance, 2008. p. 339-344.

SUTHERLAND, J. et al. Distributed Scrum: Agile Project Management with Outsourced Development Teams. In: ANNUAL HAWAII INTERNATIONAL CONFERENCE ON SYSTEM SCIENCES, 40., 2007, Waikoloa. Proceedings... IEEE Computer Society Press, 2007. p. $274-284$.

TAKEUCHI, H.; NONAKA, I. The New New Product Development Game. Harvard Business Review, p. 137-183, 1986.

TAKEUCHI H.; NONAKA I. Hitotsubashi on Knowledge Management. Singapore: John Wiley \& Sons, 2004. 250 p.

UY, E.; IOANNOU, N. Growing and Sustaining an Offshore Scrum Engagement. In: AGILE CONFERENCE, 2008, Toronto. Proceedings... Toronto: Agile Alliance, 2008. p. 345-350.

UY, E.; ROSENDAHL, R. Migrating from SharePoint to a Better Scrum Tool. In: AGILE CONFERENCE, 2008, Toronto. Proceedings... Toronto: Agile Alliance, 2008. p. 506-512.

VRIENS, C. Certifying for CMM Level 2 and ISO 9001 with XP \& Scrum. In: AGILE DEVELOPMENT CONFERENCE, 2003, Salt Lake City. Proceedings... IEEE Cumputer Society, 2003. p. 120-124. 


\section{Appendix A}

Table 2. Journals, year of publication and database of coded articles.

\begin{tabular}{|c|c|c|c|c|}
\hline Code & Authors & Journal & Year & Database \\
\hline 1 & Mann, C. and Maurer, F. & Agile Conference, p. 70-79. & 2005 & IEEE \\
\hline 2 & $\begin{array}{l}\text { Fraser, S.; Rising, L.; Ambler, S.; Cockburn, A.; } \\
\text { Eckstein, J.; Hussman, D.; Miller, R.; Striebeck, M. and } \\
\text { Thomas, D. }\end{array}$ & Dynamic Languages Symposium, p. 937-939. & 2006 & $\mathrm{ACM}$ \\
\hline 3 & Salo, O. and Abrahamsson, P. & IET Software - Volume 2, Issue 1, p. 58-64. & 2008 & AIP \\
\hline 4 & Maurer, F. and Melnik, G. & $28^{\text {th }}$ International Conference on Software Engineering. & 2006 & $\mathrm{ACM}$ \\
\hline 5 & Maurer, F. and Melnik, G. & $29^{\text {th }}$ International Conference on Software Engineering. & 2007 & $\mathrm{ACM}$ \\
\hline 6 & $\begin{array}{l}\text { Lukanuski, M.; Milano, M.; Bruin, J.; } \\
\text { Rochford, M.; Bosman, R. }\end{array}$ & Conference on Human Factors in Computing Systems. & 2008 & $\mathrm{ACM}$ \\
\hline 7 & Keenan, F. & $26^{\text {th }}$ International Conference on Software. & 2004 & $\mathrm{ACM}$ \\
\hline 8 & Smith, P. & The Journal of Product Innovation Management, p. 369-376. & 2005 & $\mathrm{ACM}$ \\
\hline 9 & Sulaiman, T.; Barton, B. and Blackburn, T. & Agile Conference. & 2006 & IEEE \\
\hline 10 & Berczuk, S. & Agile Conference, p. 382-388. & 2007 & IEEE \\
\hline 11 & Kniberg, H. and Farhang, R. & Agile Conference, p. 436-444. & 2008 & IEEE \\
\hline 12 & Vriens, C. & Agile Development Conference, p. 120-124. & 2003 & IEEE \\
\hline 13 & Paasivaara, M.; Durasiewicz, S. and Lassenius, C. & Global Software Engineering, p. 87-95. & 2008 & IEEE \\
\hline 14 & Sutherland, J.; Viktorov, A.; Blount, J. and Puntikov, N. & System Sciences, p. 274a. & 2007 & IEEE \\
\hline 15 & Dybå, T. and Dingsøyr, T & SINTEF ICT, S.P. Andersensv. & 2008 & Science Direct \\
\hline 16 & $\begin{array}{l}\text { Sutherland, J.; Schoonheim, G.; Rustenburg, E. and } \\
\text { Rijk, M. }\end{array}$ & Agile Conference, p. 339-344. & 2008 & IEEE \\
\hline 17 & Sutherland, J. & Agile Conference, p. 90-99. & 2005 & IEEE \\
\hline 18 & Judy, K. and Krumins-Beens, I. & $\begin{array}{l}\text { Hawaii International Conference on System Sciences, } \\
\text { p. 462-462. }\end{array}$ & 2008 & IEEE \\
\hline 19 & Uy, E. and Ioannou, N. & Agile Conference, p. 345-350. & 2008 & IEEE \\
\hline 20 & Barton, B. and Campbell, E. & System Sciences, p. 275a. & 2007 & IEEE \\
\hline 21 & Smits, H. and Pshigoda, G. & Agile Conference, p. 371-375. & 2007 & IEEE \\
\hline 22 & Rayhan, S. and Haque, N. & Agile Conference, p. 351-355. & 2008 & IEEE \\
\hline 23 & Scotland, K. and Boutin, A. & Agile Conference, p. 191-195. & 2008 & IEEE \\
\hline 24 & Marçal, A.; Freitas, B.; Soares, F. and Belchior, A. & Software Engineering Workshop, p. 13-22. & 2007 & IEEE \\
\hline 25 & Mahnic, V. and Zabkar, N. & $\begin{array}{l}\text { International Conference on Computer Engineering and } \\
\text { Applications. }\end{array}$ & 2008 & ACM \\
\hline 26 & Uy, E. and Rosendahl, R. & Agile Conference, p. 506-512. & 2008 & IEEE \\
\hline 27 & Lewis, J. and Neher, K. & Agile Conference, p. 389-394. & 2007 & IEEE \\
\hline 28 & Edwards, M. & Agile Conference, p. 413-416. & 2008 & IEEE \\
\hline 29 & Lyon, R. and Evans, M. & Agile Conference, p. 395-400. & 2008 & IEEE \\
\hline 30 & Sutherland, J.; Jakobsen, C. Johnson, K. & Agile Conference, p. 272-278. & 2007 & IEEE \\
\hline 31 & Sutherland, J.; Jakobsen, C. and Johnson, K. & $\begin{array}{l}\text { Hawaii International Conference on System Sciences, } \\
\text { p. } 466-466 .\end{array}$ & 2008 & IEEE \\
\hline 32 & Moore, R.; Reff, K.; Graham, J. and Hackerson, B. & Agile Conference, p. 175-180. & 2007 & IEEE \\
\hline 33 & Bates, C. and Yates, S. & $\begin{array}{l}\text { International workshop on Cooperative and human aspects } \\
\text { of software engineering. }\end{array}$ & 2008 & ACM \\
\hline 34 & Marchenko, A. and Abrahamsson, P. & Agile Conference, p. 15-26. & 2008 & IEEE \\
\hline 35 & Doernhoefer, M. & $\begin{array}{l}\text { ACM SIGSOFT Software Engineering Notes - Volume 29, } \\
\text { Issue } 5 .\end{array}$ & 2004 & ACM \\
\hline 36 & Rising, L. and Janoff, N. & Software, IEEE - Volume 17, Issue 4, p. 26-32. & 2000 & IEEE \\
\hline 37 & Cristal, M.; Wildt, D. and Prikladnicki, R. & Global Software Engineering, p. 222-226. & 2008 & IEEE \\
\hline 38 & Sanders, D. & $\begin{array}{l}\text { Journal of Computing Sciences in Colleges, Volume 23, } \\
\text { Issue } 1 .\end{array}$ & 2007 & $\mathrm{ACM}$ \\
\hline 39 & $\begin{array}{l}\text { Berczuk, S.; Harrison, N.; Henney, K.; Kerievsky, J.; } \\
\text { Rising, L.; Schwaber, K. and Woolf, B. }\end{array}$ & $\begin{array}{l}\text { International Conference on Object-Oriented Programming, } \\
\text { Systems, Languages, and Applications, p. 26-30. }\end{array}$ & 2003 & $\mathrm{ACM}$ \\
\hline 40 & Bruegge, B. and Schiller, J. & Database and Expert Systems Application, p. 125-129. & 2008 & IEEE \\
\hline
\end{tabular}


Table 3. Type of study, approach methods, researcher affiliation, period of coded article analysis and the Scrum benefits mentioned.

\begin{tabular}{|c|c|c|c|c|c|c|c|c|c|c|c|c|c|}
\hline \multirow{2}{*}{ Code } & \multirow{2}{*}{ Type of study } & \multirow{2}{*}{ Approach } & \multirow{2}{*}{$\begin{array}{c}\text { Author } \\
\text { affiliation }\end{array}$} & \multirow{2}{*}{$\begin{array}{c}\text { Period of } \\
\text { analysis }\end{array}$} & \multicolumn{9}{|c|}{ Scrum benefits (see Table 1) } \\
\hline & & & & & $\mathbf{A}$ & B & C & D & $\mathbf{E}$ & $\mathbf{F}$ & G & $\mathbf{H}$ & I \\
\hline 1 & Case study & Qualitative & $\mathrm{U}$ & Longitudinal & $\mathrm{x}$ & - & - & - & - & - & - & - & - \\
\hline 2 & Theorectical-conceptual & Qualitative & $\mathrm{C}$ & Current & - & - & - & - & - & - & - & - & - \\
\hline 3 & Survey & Quantitative & $\mathrm{R}$ & Current & $\mathrm{x}$ & - & - & - & - & - & - & - & - \\
\hline 4 & Theorectical-conceptual & Qualitative & $\mathrm{U}$ & Current & - & - & - & - & - & - & - & - & - \\
\hline 5 & Theorectical-conceptual & Qualitative & $\mathrm{U}$ & Current & $\mathrm{x}$ & $\mathrm{x}$ & - & - & - & - & - & - & - \\
\hline 6 & Theorectical-conceptual & Qualitative & $\mathrm{C}$ & Current & - & - & - & - & - & - & - & - & - \\
\hline 7 & Theorectical-conceptual & Qualitative & $\mathrm{U}$ & Current & - & - & - & - & - & - & - & - & - \\
\hline 8 & Literature review & Qualitative & $\mathrm{C}$ & Current & - & - & - & - & - & - & - & - & - \\
\hline 9 & Experimental & Quantitative & $\mathrm{C}$ & Current & - & - & $\mathrm{x}$ & - & - & - & - & - & - \\
\hline 10 & Case study & Qualitative & $\mathrm{C}$ & Current & - & $\mathrm{x}$ & - & - & - & - & - & - & - \\
\hline 11 & Case study & Qualitative & $\mathrm{C}$ & Current & - & - & - & $\mathrm{x}$ & - & - & - & - & - \\
\hline 12 & Case study & Qualitative & $\mathrm{C}$ & Current & - & - & - & - & - & - & - & - & - \\
\hline 13 & Case study & Qualitative & $\mathrm{U}$ & Current & - & $\mathrm{x}$ & - & $\mathrm{x}$ & $\mathrm{x}$ & - & - & - & - \\
\hline 14 & Case study & Qualitative & $\mathrm{C}$ & Current & - & - & - & - & - & $\mathrm{x}$ & - & - & - \\
\hline 15 & Literature review & Qualitative & $\mathrm{R}$ & Current & - & - & - & - & - & - & - & - & - \\
\hline 16 & Case study & Qualitative & $\mathrm{C}$ & Current & - & - & - & - & $\mathrm{x}$ & - & $\mathrm{x}$ & $\mathrm{x}$ & - \\
\hline 17 & Theorectical-conceptual & Qualitative & $\mathrm{C}$ & Current & $\mathrm{x}$ & $\mathrm{x}$ & $\mathrm{x}$ & $\mathrm{x}$ & $\mathrm{x}$ & $\mathrm{x}$ & $\mathrm{x}$ & - & - \\
\hline 18 & Theorectical-conceptual & Qualitative & $\mathrm{C}$ & Current & - & $\mathrm{x}$ & - & - & - & - & - & - & - \\
\hline 19 & Case study & Qualitative & $\mathrm{C}$ & Current & - & - & - & - & - & - & - & - & - \\
\hline 20 & Theorectical-conceptual & Qualitative & $\mathrm{C}$ & Current & $\mathrm{x}$ & $\mathrm{x}$ & $\mathrm{x}$ & $\mathrm{x}$ & $\mathrm{x}$ & - & $\mathrm{x}$ & - & - \\
\hline 21 & Case study & Qualitative & $\mathrm{C}$ & Current & - & $\mathrm{x}$ & - & - & $\mathrm{x}$ & - & - & - & - \\
\hline 22 & Case study & Qualitative & $\mathrm{C}$ & Current & - & $\mathrm{x}$ & - & - & - & - & - & - & - \\
\hline 23 & Case study & Qualitative & $\mathrm{C}$ & Current & - & - & - & - & - & - & - & - & - \\
\hline 24 & Theorectical-conceptual & Qualitative & $\mathrm{U}$ & Current & - & $\mathrm{x}$ & $\mathrm{x}$ & - & $\mathrm{x}$ & - & $\mathrm{x}$ & - & - \\
\hline 25 & Theorectical-conceptual & Qualitative & $\mathrm{C}$ & Current & - & - & - & - & - & - & - & - & - \\
\hline 26 & Case study & Qualitative & $\mathrm{C}$ & Current & - & - & - & - & - & - & - & - & - \\
\hline 27 & Case study & Qualitative & $\mathrm{C}$ & Current & - & - & - & - & - & - & - & - & - \\
\hline 28 & Action research & Qualitative & $\mathrm{C}$ & Current & - & - & - & - & - & - & - & - & $\mathrm{x}$ \\
\hline 29 & Case study & Qualitative & $\mathrm{C}$ & Current & - & - & - & - & $\mathrm{x}$ & - & - & - & - \\
\hline 30 & Theorectical-conceptual & Qualitative & $\mathrm{C}$ & Current & $\mathrm{x}$ & - & $\mathrm{x}$ & - & $\mathrm{x}$ & - & $\mathrm{x}$ & - & - \\
\hline 31 & Theorectical-conceptual & Qualitative & $\mathrm{C}$ & Current & $\mathrm{x}$ & - & $\mathrm{x}$ & - & $\mathrm{x}$ & - & $\mathrm{x}$ & - & - \\
\hline 32 & Action research & Qualitative & $\mathrm{C}$ & Current & - & $\mathrm{x}$ & - & $\mathrm{x}$ & - & - & $\mathrm{x}$ & - & - \\
\hline 33 & Teórico-conceitual & Qualitative & $\mathrm{U}$ & Current & $\mathrm{x}$ & $\mathrm{x}$ & - & - & - & - & - & - & - \\
\hline 34 & Case study & Qualitative & $\mathrm{R}$ & Current & - & - & - & - & - & - & - & - & - \\
\hline 35 & Literature review & Qualitative & $\mathrm{C}$ & Current & - & - & - & - & - & - & - & - & - \\
\hline 36 & Theorectical-conceptual & Qualitative & $\mathrm{C}$ & Current & $\mathrm{x}$ & $\mathrm{x}$ & - & - & $\mathrm{x}$ & - & - & - & - \\
\hline 37 & Case study & Qualitative & $\mathrm{U}$ & Current & - & - & - & - & $\mathrm{x}$ & - & $\mathrm{x}$ & - & - \\
\hline 38 & Theorectical-conceptual & Qualitative & $\mathrm{U}$ & Current & - & $\mathrm{x}$ & - & - & - & - & $\mathrm{x}$ & $\mathrm{x}$ & - \\
\hline 39 & Theorectical-conceptual & Qualitative & $\mathrm{C}$ & Current & - & - & - & - & - & - & - & - & - \\
\hline 40 & Theorectical-conceptual & Qualitative & $\mathrm{U}$ & Current & - & - & - & - & - & $\mathrm{x}$ & $\mathrm{x}$ & $\mathrm{x}$ & - \\
\hline
\end{tabular}

$\mathrm{U}=$ University; $\mathrm{R}=$ Research center; $\mathrm{C}=$ Company. 